\title{
Benthic biotope index for classifying habitats in the sado estuary: Portugal
}

\author{
S. Caeiro ${ }^{\text {a,* }}$, M.H. Costa ${ }^{\text {b }}$, P. Goovaerts ${ }^{\text {c }}$, F. Martins ${ }^{\text {d }}$ \\ a IMAR, Department of Exact and Technological Sciences of the Portuguese Distance Learning University, \\ R. Escola Politecnica, 147, 1269-001 Lisbon, Portugal \\ b IMAR, Faculty of Science and Technology of the New University of Lisbon, \\ Quinta da Torre 2829-516 Caparica, Portugal \\ c BioMedware, Inc., 516 North State Street, Ann Arbor, USA \\ d EST, Universidade do Algarve, Campus da Penha, 8000 Faro, Portugal
}

Received 20 April 2004; received in revised form 15 April 2005; accepted 15 April 2005

\begin{abstract}
An integration of sediment physical, chemical, biological, and toxicity data is necessary for a meaningful interpretation of the complex sediment conditions in the marine environment. Assessment of benthic community is a vital component for that interpretation, yet their evaluation is complex and requires a large expenditure of time and funds. Thus, there is a need for new tools that are less expensive and more understandable for managers. This paper presents a benthic biotope index to predict from physical and chemical variables the occurrence of macrobenthic habitats. Parameters such as sediment type, organic matter, depth, and hydrodynamic parameters were selected, through a discriminant analysis, to compute the index. Other authors have used multivariate methods to determine the benthic biotopes for Sado Estuary. The index proved to be a valid tool to classify and assess the spatial patterns of benthic habitat and to synthesize stress biotope gradients.
\end{abstract}

(c) 2005 Elsevier Ltd. All rights reserved.

\footnotetext{
* Corresponding author. Tel.: +351 213916300; fax: +351 213969293.

E-mail addresses: scaeiro@univ-ab.pt (S. Caeiro), mhcosta@fct.unl.pt (M.H. Costa), goovaerts@ biomedware.com (P. Goovaerts), fmartins@ualg.pt (F. Martins).
} 
Keywords: Benthic habitat; Index; Estuaries; Pollution effects; Sediment quality assessment; Biotope gradients

\section{Introduction}

The study of benthic communities is a crucial component to monitor the environmental health of estuaries. Macrobenthic fauna provide an ideal measure of the community's response to environmental disturbance and are an effective indicator of the extent and magnitude of pollution impacts in estuarine environments (Engle, Summers, \& Gaston, 1994; Weisberg et al., 1997; Borja, Franco, \& Pérez, 2000). Their advantages as pollution indicators includes: (i) they provide direct measures of the condition of the biota and may uncover problems undetected or underestimated by other methods (Borja et al., 2000); (ii) their limited mobility prevents them from escaping adverse conditions like hypoxia and accumulation of anthropogenic contaminants (Ranasinghe et al., 1994; Weisberg et al., 1997; Paul et al., 2001); (iii) they integrate responses to exposure and respond to multiple stressors over relatively long periods of time (Ranasinghe et al., 1994; Ranasinghe et al., 2002); and (iv) they have a taxonomic diversity that can usually be classified into different functional response groups (Smith et al., 2001).

Benthic communities are often associated with natural habitat gradients such as salinity and sediment type (Engle \& Summers, 1998; Paul et al., 2001). Grain size data may be used to determine the extent of recovery from sedimentary disturbance, to evaluate the benthic habitats and the structure of benthic assemblages (Gibson, Bowman, Gerritsen, \& Snyder, 2000), and to assist in providing early warning of potential impacts to the estuarine ecosystem (Gibson et al., 2000). The silt-clay content of sediments (the fraction $<63 \mu \mathrm{m}$ ) is an important factor determining the composition of the biological community at a site, and is therefore important in the assessment of the benthic community (Strobel et al., 1995). Benthic habitat gradients can also be distributed according to depth (Clarke, 1993). The fact that shallow assemblages are defined by a combination of depth and sediment type is consistent with the theory that the hydrodynamics energy profile at the bottom is the controlling factor (Gibson et al., 2000). The energy profile of water flow immediately above the sediment-water interface determines the size of particles in superficial sediment, which in turn affects benthic properties. Depth affects the energy profile because the effects of wave energy on the bottom are usually greatest in shallow areas and decrease as the distance between the surface and bottom increases (Bergen et al., 2001). Hydrodynamic events can also have a strong effect on hypoxia variation in frequency and severity. Hypoxia and organic enrichment bring significant structural changes in benthic communities and energy flow processes (Pearson \& Rosenberg, 1978; Diaz \& Rosenberg, 1995).

Many features can be used to describe an estuarine community and interpret changes in relation to human impacts, environmental variability and biological processes. McLusky and Elliott (2004) presents an overview of concepts and techniques 
for detecting and indicating change in estuarine and marine communities. Characteristics of benthic assemblages expressed as indices have been used to measure ecological status and trends of marine and estuarine environments for several decades. An index based upon several structural properties of the benthic environment and/or sediment type, can summarize the benthic data and characterize estuarine biological condition.

Benthic indices generally fall into three types based upon complexity and information content: (i) single community attribute measures or individual-species data combinations, including species diversity or abundance/biomass ratios, are used to summarize data beyond the level of individual species; (ii) multi-metric index approach are used to combine multiple measures of community response into a single index to more effectively capture the different types of response that occur at different levels of stress; (iii) multivariate methods that integrate species composition information are used to describe the assemblage patterns in a comparative multivariate space, based upon scoring of a pollution tolerance (Smith et al., 2001). A fourth type can also be considered when the index is calculated based only on the sediment habitat type, using a combination of physical and chemical data. This last type of index is distinguished from the others since it identifies habitat classes instead of community conditions.

The use of a single indicator has not proven to be ideal for monitoring estuarine environments, which has highly variable natural conditions (Engle et al., 1994). Multivariate approaches can provide higher sensitivity in characterizing benthic patterns (Warwick \& Clarke, 1991; Clarke, 1993) but their assessment and output are usually too complex to present in an easy to understand manner for managers (Clarke, 1993; Smith et al., 2001). On the contrary, indices allow one to integrate and simplify a mass of heterogeneous data, leading to better communication between scientists and nonspecialists and easier interpretation whereby quality and management goals can be set (Wilson \& Jeffrey, 1994; Alden, Dauer, Ranasinghe, Scott, \& Llansó, 2002). These qualities compensate for any sacrifice of scientific data (Wilson \& Jeffrey, 1994).

Table 1 presents a chronological list of benthic indices applied to estuarine ecosystems including data source and type. Only a few of the diversity indices are listed. They have not been considered appropriate in estuarine situations because of the low number of species that are naturally found in estuaries, and the response of this index, which to any environmental stress mimics the response to pollution (Wilson $\&$ Jeffrey, 1994).

The indices listed in Table 1 are applicable across habitat boundaries and have been developed for estuaries and coastal areas in several geographic sites around the world. Nevertheless it should be kept in mind that each of these specific indices is only appropriately applied to conditions similar to those that were used to develop the index. Most of these indices aim to identify degraded benthic invertebrate assemblages that are indicative of low dissolved oxygen concentrations in bottom water or high concentrations of chemical contaminants in sediment, which both have common pollution effects in estuaries (Ranasinghe et al., 2002). Some of the most recent indices have been verified and compared with each other through multivariate statistical analyses (e.g. Alden et al., 2002; Ranasinghe et al., 2002). Most of these indices require large databases and a non-biological classification of "good" reference sta- 
Table 1

Literature review of macrozoobenthic indices applied to estuarine ecosystems

\begin{tabular}{|c|c|c|c|c|}
\hline Author & Year & Index name & Data source & Type of index \\
\hline Gleason (1922) & 1922 & $\begin{array}{l}\text { - Gleason } \\
\text { Diversity Index } \\
\text { (G) }\end{array}$ & Benthic metrics & Single community \\
\hline $\begin{array}{l}\text { Shannon and Weaver } \\
\text { (1949) }\end{array}$ & 1949 & $\begin{array}{l}\text { - Shannon- } \\
\text { Wiener } \\
\text { Diversity Index } \\
\text { (H) }\end{array}$ & Benthic metrics & Single community \\
\hline Leppakowski (1975) & 1975 & $\begin{array}{l}\text { - Benthic } \\
\text { Pollution Index } \\
\text { (BPI) }\end{array}$ & Benthic metrics & Single community \\
\hline $\begin{array}{l}\text { Word }(1978,1979) \text { fide } \\
\text { Bascom }(1982)\end{array}$ & 1978 & $\begin{array}{l}\text { - Infauna } \\
\text { Trophic Index } \\
\text { (ITI) }\end{array}$ & Benthic metrics & Multi-metric \\
\hline $\begin{array}{l}\text { Bellan (1980), Bellan } \\
\text { et al. (1988) }\end{array}$ & 1980 & $\begin{array}{l}\text { - Annelid Index } \\
\text { of Pollution } \\
\text { (AIP) }\end{array}$ & Benthic metrics & Single community \\
\hline $\begin{array}{l}\text { Satsmadjis (1982) fide } \\
\text { Satsmadjis (1985) }\end{array}$ & 1982 & $\begin{array}{l}\text { - Pollution } \\
\text { Coefficient (P) }\end{array}$ & $\begin{array}{l}\text { Benthic metrics } \\
\text { and physical } \\
\text { parameters }\end{array}$ & Multi-metric \\
\hline Jeffrey et al. (1985) & 1985 & $\begin{array}{l}\text { - Biological } \\
\text { Quality Index } \\
\text { (BQI) }\end{array}$ & Benthic metrics & Multi-metric \\
\hline $\begin{array}{l}\text { Rhoads and Germano } \\
\text { (1986), Diaz et al. } \\
\text { (2003) }\end{array}$ & 1986 & $\begin{array}{l}\text { - Organism- } \\
\text { sediment index } \\
\text { (OSI) }\end{array}$ & $\begin{array}{l}\text { Sediment profile } \\
\text { images }\end{array}$ & Sediment habitat \\
\hline Chapman et al. (1987) & 1987 & $\begin{array}{l}\text { - Summary } \\
\text { index for } \\
\text { benthic infauna } \\
\text { Ratio-to- } \\
\text { Reference of } \\
\text { Sediment } \\
\text { Quality Triad } \\
\text { (RTR) }\end{array}$ & Benthic metrics & Multi-metric \\
\hline $\begin{array}{l}\text { Majeed (1987) } \\
\text { Grall and Glémarec } \\
\text { (1997) }\end{array}$ & 1987 & $\begin{array}{l}\text { - Biotic Indices } \\
\text { (BI) }\end{array}$ & Benthic metrics & Multi-metric \\
\hline $\begin{array}{l}\text { McManus and Pauly } \\
\text { (1990) }\end{array}$ & 1990 & $\begin{array}{l}\text { - Shannon- } \\
\text { Weiner evenness } \\
\text { proportion } \\
\text { Index (SEP) }\end{array}$ & Benthic metrics & Single community \\
\hline $\begin{array}{l}\text { McManus and Pauly } \\
\text { (1990) }\end{array}$ & 1990 & - DAP index & Benthic metrics & Single community \\
\hline $\begin{array}{l}\text { Weisberg et al. (1993), } \\
\text { Schimmel et al. (1994), } \\
\text { Strobel et al. (1995) } \\
\text { Paul et al. (1999), Paul }\end{array}$ & 1993 & $\begin{array}{l}\text { - Benthic index } \\
\text { of estuarine } \\
\text { conditions } \\
\text { (BIEC) }\end{array}$ & Benthic metrics & Multi-metric \\
\hline
\end{tabular}


Table 1 (continued)

\begin{tabular}{|c|c|c|c|c|}
\hline Author & Year & Index name & Data source & Type of index \\
\hline $\begin{array}{l}\text { Engle et al. (1994) } \\
\text { Engle and Summers } \\
\text { (1999) }\end{array}$ & 1994 & $\begin{array}{l}\text { - Benthic } \\
\text { condition } \\
\text { Index (BCI) }\end{array}$ & Benthic metrics & Multi-metric \\
\hline $\begin{array}{l}\text { Ranasinghe et al. (1994), } \\
\text { Weisberg et al. (1997), } \\
\text { Van Dolah et al. (1999), } \\
\text { Alden et al. (2002) }\end{array}$ & 1994 & $\begin{array}{l}\text { - Benthic Index } \\
\text { of biotic integrity } \\
\text { (B-IBI). }\end{array}$ & Benthic metrics & Multi-metric \\
\hline $\begin{array}{l}\text { Warwick and } \\
\text { Clarke (1995) }\end{array}$ & 1995 & $\begin{array}{l}\text { - Taxonomic } \\
\text { diversity } \\
\text { index }(\Delta) \\
\text { - Taxonomic } \\
\text { distinctness }\left(\Delta^{*}\right)\end{array}$ & Benthic metrics & $\begin{array}{l}\text { Single } \\
\text { community }\end{array}$ \\
\hline $\begin{array}{l}\text { Fairey et al. (1996) fide } \\
\text { Anderson et al. (1998) }\end{array}$ & 1996 & $\begin{array}{l}\text { - Relative benthic } \\
\text { index (RBI) }\end{array}$ & Benthic metrics & Multi-metric \\
\hline $\begin{array}{l}\text { Nilsson and } \\
\text { Rosenberg (1997) }\end{array}$ & 1997 & $\begin{array}{l}\text { - Benthic habitat } \\
\text { quality Index } \\
\text { (BHQ) }\end{array}$ & $\begin{array}{l}\text { Sediment profile } \\
\text { images }\end{array}$ & $\begin{array}{l}\text { Sediment } \\
\text { habitat }\end{array}$ \\
\hline DelValls et al. (1998) & 1998 & $\begin{array}{l}\text { - Summary index } \\
\text { for benthic infauna } \\
\text { new Maximum } \\
\text { Ratio-to-Reference of } \\
\text { Sediment Quality } \\
\text { Triad (RTM) }\end{array}$ & Benthic metrics & Multi-metric \\
\hline Roberts et al. (1998) & 1998 & $\begin{array}{l}- \text { Macrofauna } \\
\text { Monitoring Index }\end{array}$ & Benthic metrics & Multi-metric \\
\hline $\begin{array}{l}\text { Borja et al. (2000), } \\
\text { Borja et al. (2003) }\end{array}$ & 2000 & $\begin{array}{l}\text { - Marine Biotic } \\
\text { Index (BI) }\end{array}$ & Benthic metrics & Multi-metric \\
\hline Ferreira (2000) & 2000 & $\begin{array}{l}\text { - Equation index - } \\
\text { Sediment quality }\end{array}$ & $\begin{array}{l}\text { Benthic metrics, } \\
\text { pollutants, } \\
\text { bioacumulation }\end{array}$ & Multi-metric \\
\hline Eaton (2001) & 2001 & $\begin{array}{l}\text { - Biocrioteria for } \\
\text { estuarine } \\
\text { shallow water }\end{array}$ & Benthic metrics & Multi-metric \\
\hline Smith et al. (2001) & 2001 & $\begin{array}{l}\text { - Benthic Response } \\
\text { Index (BRI) }\end{array}$ & Benthic metrics & $\begin{array}{l}\text { Multivariate } \\
\text { methods }\end{array}$ \\
\hline Degraer et al. (2002) & 2002 & - Habitat model & $\begin{array}{l}\text { Physical and } \\
\text { chemical } \\
\text { parameters }\end{array}$ & $\begin{array}{l}\text { Sediment } \\
\text { habitat }\end{array}$ \\
\hline Schmidt et al. (2002) & 2002 & $\begin{array}{l}\text { - Modified } \\
\text { Ecotoxicological } \\
\text { Rating (METR) }\end{array}$ & $\begin{array}{l}\text { Physical, chemical } \\
\text { and toxicological } \\
\text { parameters }\end{array}$ & $\begin{array}{l}\text { Sediment } \\
\text { habitat and } \\
\text { single } \\
\text { community }\end{array}$ \\
\hline
\end{tabular}

tions (e.g. Engle \& Summers, 1999; Paul et al., 2001; Alden et al., 2002), which sometimes are difficult to identify and vary for unknown reasons often unrelated to contamination (Anderson et al., 1998).

Since the collection of data to retrieve a detailed bathymetric-sedimentological map of an area is less time-consuming than data collection for a detailed macroben- 
thic map, models that provide a powerful time-cost-efficient tool to retrieve a fullcoverage view of the spatial distribution of the macrobenthic potential should be used (Degraer et al., 2002). The indices OSI, BHQ and Habitat (Table 1) are good examples of how benthic habitat quality can be assessed using only sedimentological data. The index METR adds toxicity data to the sedimentological data. These kinds of indices, although promising to assess benthic system's viability or health (Diaz, Cutter, \& Dauer, 2003), are still underexplored and poorly understood.

The aim of this work is to develop an index of benthic biotopes for classifying habitats, which is based on physical and chemical variables that are strongly related to community patterns. By benthic biotopes we mean a classification of habitats initially derived from benthic composition and structure. The benthic data used in this paper was analyzed previously by Rodrigues (1992). First, the benthic index is developed using discriminant analysis which is introduced below. After validation using Rodrigues' data, the benthic habitats are predicted at new locations where physical and chemical variables were recently measured. Then, the benthic index is integrated with contaminants and toxicity indices for overall sediment quality assessment and will become part of a management and data system for Sado Estuary. The management units were delineated based on sediment parameters like fine fraction contents $(\mathrm{FF})$, total organic matter (TOM) and redox potential in a previous study (Caeiro, Goovaerts, Painho, \& Costa, 2003a).

\section{Methods}

\subsection{Study area}

The Sado Estuary is the second largest in Portugal with an area of approximately 24,000 ha. It is located on the west coast of Portugal. Most of the estuary is classified as a natural reserve, but with many industries and harbour-associated activities mainly on the northern margin of the estuary (Caeiro, Costa, Paínho, \& Ramos, 2002). The Sado Estuary is characterized by a North Channel with weaker residual current flow, which enhances accumulation of sediment. As a result, locally introduced pollutants settle out rather than are transported away. The southern channel, separated from the North Channel by sandbanks, is highly dynamic and tides are primarily responsible for water circulation. Geometric characteristics distinguish the outer estuary (our study area) from the inner estuary, corresponding to a narrow channel (Alcácer channel). The inner part of the outer estuary, (entrances of Águas de Moura and Alcácer Channels), is quite shallow with tidal flats (Rodrigues \& Quintino, 2002).

\subsection{Benthic biotopes of Sado Estuary}

A benthic survey was undertaken in the outer estuary in 1986, where superficial sediments and macrofauna were sampled at 131 locations (Rodrigues, 1992) (Fig. 1). This study allowed the identification of benthic biotopes obtained through 


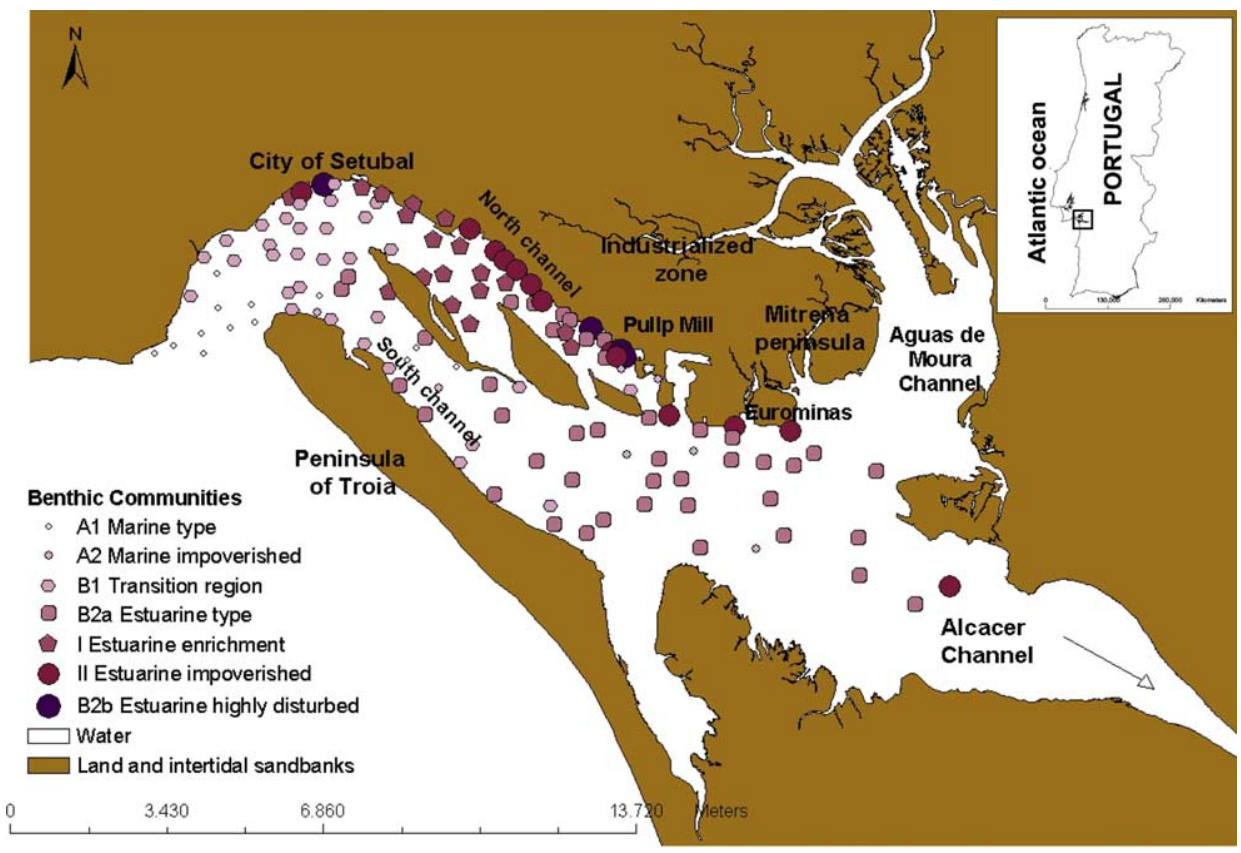

Fig. 1. Location map of 131 sampling locations and benthic communities in Sado Estuary. Data from Rodrigues (1992). Coastal line from Caeiro et al. (2003b).

classification analysis (TWINSPAN cluster classification). To evaluate the relation between those biotopes and the prevailing hydrophysical and sedimentary conditions in the outer estuary, ordination analyses (canonical correspondence and simple correspondence) were performed on the following physical and chemical parameters: fine fraction (FF), sand, gravel, total organic matter (TOM), depth, shear stress, velocity, temperature and flow. The ordination analyses suggested a very good agreement between the conclusions drawn from the analysis of the biological data alone and those from the imposed variability of the measured physical and chemical variables (Rodrigues, 1992) (Table 2).

The benthic biotopes assessed in Rodrigues' study were (Table 2 and Fig. 1):

Marine type $\left(\mathrm{A}_{1}\right)$ - 13 stations - This community corresponds to the clean coarse sands of the mouth of the estuary and southern channel with high currents and large depth.

Marine impoverished $\left(\mathrm{A}_{2}\right)-8$ stations - This community is located in the upper region of the estuary, spread over 6 small areas. This community has lower values of species richness $(s)$, biomass $(b)$, abundance $(a)$ and species diversity $\left(H^{\prime}\right)$, relatively to the marine type, and the lowest value of $b$ among all biotopes. When compared with the marine type community these stations display an increase in silt and total organic matter and the most characteristic species disappear.

Transition region $\left(\mathrm{B}_{1}\right)$ - 31 stations - This community is located in a large area inside the estuary after the entrance, more through the southern than the northern 
channel. It is characterized by species of both the marine and the estuarine type communities, together with an important proportion of species only present in this region. This community has the highest mean species richness and $H^{\prime}$, one of the highest $b$ and $a$ and the lowest proportion of species sampled only once in each affinity group, compared with the whole estuary. The stations belonging to this community type have higher mean silt and total organic matter content, and lower velocity and flow relatively to the marine type community.

Estuarine type $\left(\mathrm{B}_{2 a}\right)-43$ stations - This community type comprises the majority of the southern channel and the upper part of the estuary. The mean $s, a, b$ and $H^{\prime}$ were all below those observed in the transition region, yet most means exceed those obtained in the marine type community.

Estuarine enriched (I) - 19 location - This community is located in the northern channel, mainly in a large area that borders the northern margin of the intertidal sandbanks. The average silt, sand, gravel and total organic matter content of this region clearly indicate an increase in fine, organic sediments, and a decrease in flow, velocity and shear stress in comparison to the estuarine type area. This region also shows higher values of $s, a b$ and $H^{\prime}$, relatively to the estuarine type, and the highest proportion of species with sampling frequency higher than $50 \%$.

Estuarine impoverished (II) - 13 stations - This community is located near the northern margin, in the vicinity of the industrial complex and the urban sewage outfall, spread over 5 elongated areas. This region is characterized by organic and silt enrichment and a low hydrodynamics and depth relatively to the previously described regions. The stations that comprise this region have the lowest $a$ and $b$ within the estuarine community.

Estuarine highly disturbed $\left(\mathrm{B}_{2 b}\right)-4$ stations - This community includes the most disturbed areas of the estuarine community. These stations are mainly located in three small areas in the vicinity of the Setúbal city sewage outfall and pulp mill outfall. This community is characterized by the lowest mean species richness and diversity of the whole estuary, yet it has the highest mean abundance per site. The mean silt, sand, gravel and total organic content of these areas indicate a strong organic enrichment, combined with the lowest hydrodynamics and depth.

Other studies recently conducted in the estuary (in 1999 Carvalho, Ravara, Quintino, \& Rodrigues, 2001 and in 1997 Rodrigues \& Quintino, 2002) showed that overall, the biological succession did not undergo any significant changes, especially as far as the most characteristic species are concerned. However, according to those studies, recent dredging (1995) caused water circulation changes and decreases in the mean levels of the fine fraction and organic matter in the sediment at the transition assemblages.

\subsection{Index development}

Owing to the strong relation found between the benthic communities and the physical and chemical parameters described above, a forward stepwise discriminant analyses (SDA) was applied to the standardized dataset of 131 stations. Discriminant analysis approaches have been largely used to combine benthic community metrics 
Table 2

Summary statistics of the physical, chemical and biological variables in each biotope type for Sado Estuary (data from Rodrigues, 1992)

\begin{tabular}{|c|c|c|c|c|c|c|c|c|c|c|c|c|}
\hline & \multicolumn{8}{|c|}{ Physical and chemical variables } & \multicolumn{4}{|c|}{ Biological variables } \\
\hline & $\begin{array}{l}\text { Fine } \\
\text { fraction } \\
(\%)\end{array}$ & $\begin{array}{l}\text { Sand } \\
(\%)\end{array}$ & $\begin{array}{l}\text { Gravel } \\
(\%)\end{array}$ & $\begin{array}{l}\text { Total } \\
\text { organic } \\
\text { matter } \\
(\%) \\
\end{array}$ & $\begin{array}{l}\text { Shear stress } \\
(\% \text { of the } \\
\text { maximum } \\
\text { value })\end{array}$ & $\begin{array}{l}\text { Flow } \\
\left(\mathrm{m}^{2} \mathrm{~s}^{-1}\right)\end{array}$ & $\begin{array}{l}\text { Velocity } \\
\left(\mathrm{m} \mathrm{s}^{-1}\right)\end{array}$ & $\begin{array}{l}\text { Depth } \\
\text { (m) }\end{array}$ & $\begin{array}{l}\text { Species } \\
\text { richness }(s) \\
\left(\mathrm{sp} .0 .1 \mathrm{~m}^{-2}\right)\end{array}$ & $\begin{array}{l}\text { Mean } \\
\text { biomass per } \\
\text { site }(b) \\
\left(\text { g. } 0.1 \mathrm{~m}^{-2}\right) \\
\end{array}$ & $\begin{array}{l}\text { Mean } \\
\text { abundance } \\
\text { per site }(a) \\
\text { (ind. } 0.1 \mathrm{~m}^{-2} \text { ) }\end{array}$ & $\begin{array}{l}\text { Species } \\
\text { diversity } \\
\left(H^{\prime}\right)\end{array}$ \\
\hline \multicolumn{13}{|l|}{$\overline{\mathrm{A}_{1} \text { Marine type }}$} \\
\hline Mean & 2.1 & 89.8 & 8.0 & 0.5 & 100 & 7.9 & 0.4 & 13.4 & 32 & 5.7 & 218 & 5.2 \\
\hline Standard deviation & 1.5 & 11.5 & 10.5 & 0.1 & 37 & 5.2 & 0.2 & 9.1 & & & & \\
\hline \multicolumn{13}{|c|}{$\mathrm{A}_{2}$ Marine impoverished } \\
\hline Mean & 13.9 & 85.7 & 0.4 & 2.4 & 50 & 2.7 & 0.3 & 5.9 & 17 & 3.1 & 133 & 3.2 \\
\hline Standard deviation & 33.2 & 33.0 & 0.5 & 4.7 & 32 & 2.7 & 0.1 & 5.2 & & & & \\
\hline \multicolumn{13}{|l|}{$\mathrm{B}_{1}$ Transition region } \\
\hline Mean & 15.8 & 80.0 & 4.2 & 2.2 & 51 & 3.3 & 0.3 & 10.9 & 64 & 36.5 & 897 & 5.8 \\
\hline Standard deviation & 15.4 & 16.3 & 7.8 & 1.6 & 29 & 2.7 & 0.1 & 9.0 & & & & \\
\hline \multicolumn{13}{|l|}{$\mathrm{B}_{2 a}$ Estuarine type } \\
\hline Mean & 24.7 & 73.5 & 1.9 & 2.5 & 62 & 2.5 & 0.3 & 6.6 & 34 & 17.7 & 402 & 4.3 \\
\hline Standard deviation & 18.0 & 17.2 & 2.6 & 1.9 & 26 & 1.5 & 0.1 & 3.4 & & & & \\
\hline \multicolumn{13}{|c|}{ I Estuarine enrichment } \\
\hline Mean & 41.2 & 57.4 & 1.4 & 5.1 & 34 & 1.9 & 0.2 & 6.3 & 49 & 36.8 & 728 & 4.7 \\
\hline Standard deviation & 17.1 & 16.0 & 3.5 & 2.1 & 15 & 1.0 & 0.1 & 3.3 & & & & \\
\hline \multicolumn{13}{|c|}{ II Estuarine impoverished } \\
\hline Mean & 72.6 & 27.1 & 0.4 & 7.6 & 25 & 1.2 & 0.2 & 5.7 & 18 & 6.4 & 105 & 4.6 \\
\hline Standard deviation & 22.0 & 21.2 & 0.8 & 3.4 & 19 & 0.8 & 0.1 & 2.1 & & & & \\
\hline \multicolumn{13}{|c|}{$\mathrm{B}_{2 b}$ Estuarine highly disturbed } \\
\hline Mean & 75.1 & 23.6 & 1.3 & 9.8 & 10 & 0.4 & 0.1 & 4.3 & 12 & 19.6 & 4002 & 0.3 \\
\hline Standard deviation & 27.9 & 25.6 & 2.5 & 2.3 & 15 & 0.6 & 0.1 & 0.6 & & & & \\
\hline
\end{tabular}


into a benthic index (e.g. Engle et al., 1994; Strobel et al., 1995; Engle \& Summers, 1999; Paul et al., 2001) and less frequently used to combine physical and chemical parameters. This analysis was conducted in order to select a subset of the candidate physical and chemical parameters that best discriminate between the seven benthic biotopes and to determine which linear combination of these variables showed the most substantial difference among those biotopes.

The SDA was computed for $n$ variables with $n$ steps, selecting variables with a $F$ value larger than 1 for entering the analysis, and using a tolerance value (variable's redundancy) higher than 0.01 for each variable.

Temperature was not used in the SDA since it is the environmental parameter with the smallest discriminant power according to the ordination analysis and it exhibits low variability among community types. In general, the other parameters have averaged values that differ between communities and display a clear gradient from marine type to estuarine high disturbed communities (Table 2). Pearson correlations were calculated for the dataset to determine the presence of any redundancy among variables (Engle \& Summers, 1999). The variables were standardized (centred and scaled) for the analysis, thus treating them with equal importance.

There was no need to adjust for the effect of salinity, as was done in other studies (Engle et al., 1994; Paul et al., 2001), since salinity varies only between $29 \%$ and $37 \%$ in the study area (Rodrigues, 1992).

In order to validate the discriminant function using a jackknife approach, the entire data set was divided into a prediction $(70 \%$ of data) and a validation sub-set according to a proportionately stratified sampling procedure (e.g. Hair, Anderson, $\&$ Tatham, 1992). Other proportions for the two subsets were investigated to determine the impact of sampling density on the results.

In order for the predictive accuracy of the discriminant function to be acceptable, it must exceed the percentage of validation data that could be classified correctly by chance. This percentage is calculated using the proportional chance criterion (Hair et al., 1992) as:

$$
C_{\text {pro }}=\sum_{i=1}^{z} P_{i}^{2},
$$

where $C_{\text {pro }}$ is the proportional chance criterion; $i$, the index for the $z$ communities (1 to $z$ ); $P_{i}$, the proportion of individuals in community $i$.

The maximum chance criterion $\left(C_{\max }\right)$ was also computed from the percentage of the total sample represented by the largest community group (Hair et al., 1992).

New observations are allocated to the community with the highest standardized total discriminant score from the SDA classification functions, with a posterior probability of the predictive choice:

$$
S_{z}=\left(\sum_{j=1}^{n} W_{z j} * V_{j}\right)+C_{z},
$$

where $S_{z}$ is the classification score for community $z ; V_{j}$, the observed value for the variable $j$ (1 to $n$ ); $W_{z j}$, the weight for the variable $j$ in community $z ; C_{z}$, the constant for the community $z$. 
The benthic biotope index $\left(B_{\text {bio }}\right)$ values was then calculated from the posterior probabilities of occurrence for each observation. The index values range from 1 to $z$ on a continuous scale and are computed as follows:

$$
B I_{\text {bio }}=\sum_{j=1}^{z} Z_{i} * \operatorname{prob}_{i},
$$

where $\operatorname{Prob}_{i}$ is the posterior probabilities of occurrence of the corresponding community $i ; Z_{i}$, the number of the community $i$, from 1 to $z$.

The communities were numbered from 1 to $z$ in accordance to an increase gradient of organic load (from marine type to estuarine high disturbed communities) according to Pearson and Rosenberg (1978) paradigm.

The $B I_{\text {bio }}$ index was used for prediction of the benthic biotopes at 77 stations sampled in the outer Sado Estuary between October 2000 and January 2001, where physical and chemical parameters were measured. The sampling design was chosen to assess the sediment quality of management units previously delineated (Caeiro et al., 2004). Total organic matter (loss on ignition), fine fraction $(<63 \mu \mathrm{m})$ (hydraulic separation), (Caeiro et al., 2003a), sand (63-2000 $\mu \mathrm{m})$ and gravel (>2000 $\mu \mathrm{m})$ (dry sieving) were determined for each location. The values of the hydrodynamic variables for these same locations were predicted using an updated hydrodynamic model previously elaborated for the outer estuary (Martins, Leitão, Silva, \& Neves, 2001) and used in Rodrigues' study. These values are derived through integration of the transient model results computed over a simulated fortnight time period $(330 \mathrm{~h})$ using a time step of $5 \mathrm{~min}$. Depth, water flow and velocity values were calculated using the arithmetic mean of instantaneous values for that site during the simulated running period. The maximum value observed during the simulated running time period was used for shear stress values at each location.

Statistical analyses (i.e. computation of Eq. (2) and $P r o b_{i}$ in Eq. (3)) were conducted using Statistica ${ }^{\circledR} 6.0$ software. To visualize the index results within coastal area of Sado Estuary and management units, ArcGIS 8.0 ${ }^{\circledR}$ GIS software was used. Geostatistical Analyst ${ }^{\circledR}$ ArcGiS extension was used to perform kriging interpolations of the results. The median values of the stations were calculated for $B I_{\text {bio }}$ index visualization in each management unit.

\section{Results and discussion}

\subsection{Index calculation and validation}

Discriminant analysis if typically an iterative procedure. SDA suggests variables that best discriminate between groups of observations (here benthic communities). First SDA selects the variables that enter the model and only then the classification functions for each community are computed and used directly to classify stations. Given the Mahalanobis distances of a station to the different community centroids, the posterior classification probabilities are derived for each group. 
In the first stepwise discriminant analysis (Model I) sand and gravel variables were not included in the model (see Table 3). Sand percentages are strongly negatively correlated with fine fraction $(-0.98$, Table 4$)$, which was selected in the first step of the procedure, so percentage sand is redundant for the analysis. The strong association between size of silt/clay fraction and benthic community is well known and established (e.g. Engle \& Summers, 1998; McRae, Camp, Lyons, \& Dix, 1998; Borja et al., 2000). Gravel percentages are not only correlated with FF but also have large relative standard deviations in each biotope type (see Table 2). For these reasons sand and gravel variables were not used as input variables in later models.

Model I has a total percentage of correct classification (hit ratio) of $58 \%$ in the prediction sub-set and $53 \%$ in the validation sub-set. According to the maximum chance criterion $\left(C_{\max }\right)$ the highest probability of correct classification by chance would be $34 \%$ and according to the proportional chance criterion $\left(C_{\text {pro }}-\right.$ Eq. (1) this percentage would be $21 \%$. Since $C_{\text {max }}$ is greater than $C_{\text {pro }}$, the maximum chance criterion is the one to outperform. The hit ratio for the validation set exceeds $C_{\max }$ criterion, so the discriminant model was considered valid. However, the percentage of correct classification in the predictive and validation sub-sets was $0 \%$ for community $\mathrm{A}_{2}$ (Table 3 ). This community was only found at 8 stations in the total data set, and the physical and chemical parameters of this community's small areas have a larger variance and are far from the gradient of organic load enrichment found from marine type to estuarine disturbed communities (Table 2). In addition, the community $\mathrm{B}_{2 b}$ although with a hit ratio of $33 \%$, does not have any correctly classified station in the validation sub-set (Table 3). This community looks reasonably well defined by the physical and chemical parameters (Table 2), but it was only found in 4 stations (Fig. 1) which makes prediction unreliable. A 50/50 proportion for the prediction and validation sub-sets was also investigated and it led to a similar misclassification of all data belonging to $\mathrm{A}_{2}$ and $\mathrm{B}_{2 b}$. Even when using the whole dataset (131 sampling points) the misclassification rate for $A_{2}$ was $100 \%$, although it was zero for $\mathrm{B}_{2 b}$. For these reasons the communities $\mathrm{A}_{2}$ and $\mathrm{B}_{2 b}$ were not included in later models. Using fewer communities in the SDA will lead to a loss of information by the index but a gain in its prediction accuracy over a widespread area (Degraer et al., 2002).

Model II was computed without $\mathrm{A}_{2}$ and $\mathrm{B}_{2 b}$ communities and the sand and gravel variable. The total hit ratio improved not only in the predictive $(63.9 \%)$ but also in the validation datasets $(63.9 \%)$ (Table 3$)$. These values exceed $C_{\max }$ and $C_{\text {prop }}(36 \%$ and $25 \%$, respectively for 5 groups).

In both Models I and II, TOM and depth contribute little to the discriminatory power of the model (see Table 3, $p$ values higher than 0.05 ) and were the last variables to enter the model. TOM is strongly correlated with fine fraction (0.90) and significantly correlated with all other variables. Depth, although significantly correlated with most of the variables, had lower correlation values (Table 4).

Sand, gravel and TOM were not included in Model III. The hit ratio of the prediction sub-set (60.2) is slightly less than Model II, but higher than for Model I. Nevertheless the percentage of correct classification in the validation sub-set equals the one obtained for Model II (63.9\%) (Table 3). 
Table 3

Results of the forward stepwise discriminant analyses conducted for combining the physical and chemical variables into the $B I_{\text {bio }}$

\begin{tabular}{|c|c|c|c|c|c|c|c|c|c|c|c|}
\hline \multirow[t]{2}{*}{ Variables included in the analysis } & \multirow[t]{2}{*}{ Wilk's Lambda } & \multirow[t]{2}{*}{$F$} & \multirow[t]{2}{*}{$P$} & \multicolumn{8}{|c|}{ Communities correct classifications $(\%)$} \\
\hline & & & & $\mathrm{A} 1$ & B1 & $\mathrm{I}$ & II & $\mathrm{B} 2 \mathrm{~b}$ & $\mathrm{~A} 2$ & $\mathrm{~B} 2 \mathrm{a}$ & Total \\
\hline Model I & 0.202 & 4.261 & $<0.000$ & \multicolumn{8}{|c|}{ Prediction dataset (validation dataset) } \\
\hline $\mathrm{FF}$ & 0.256 & 3.476 & 0.004 & & & & & \multirow{6}{*}{$\begin{array}{l}33.3 \\
(0)\end{array}$} & \multirow{6}{*}{$\begin{array}{r}0 \\
(0)\end{array}$} & \multirow{6}{*}{$\begin{array}{c}76.7 \\
(92.3)\end{array}$} & \multirow{6}{*}{$\begin{array}{c}58.24 \\
(52.5)\end{array}$} \\
\hline Flow & 0.263 & 3.954 & 0.002 & & & & & & & & \\
\hline Shear stress & 0.258 & 3.606 & 0.003 & 66.7 & 45.5 & 46.2 & 77.8 & & & & \\
\hline Velocity & 0.252 & 3.241 & 0.007 & $(75.0)$ & $(22.2)$ & (0) & (100) & & & & \\
\hline Depth & 0.220 & 1.125 & 0.356 & & & & & & & & \\
\hline TOM & 0.218 & 1.019 & 0.419 & & & & & & & & \\
\hline Model II & 0.217 & 5.860 & $<0.000$ & \multicolumn{8}{|c|}{ Prediction dataset (validation dataset) } \\
\hline $\mathrm{FF}$ & 0.257 & 3.343 & 0.014 & & & & & & & & \\
\hline Flow & 0.283 & 5.537 & 0.0006 & & & & & & & \multirow{5}{*}{$\begin{array}{c}76.7 \\
(84.6)\end{array}$} & \multirow{5}{*}{$\begin{array}{c}63.9 \\
(63.9)\end{array}$} \\
\hline Shear stress & 0.284 & 5.606 & 0.0005 & \multirow{4}{*}{$\begin{array}{c}66.7 \\
(75.0)\end{array}$} & \multirow{4}{*}{$\begin{array}{c}50.0 \\
(33.3)\end{array}$} & \multirow{4}{*}{$\begin{array}{l}46.2 \\
(50)\end{array}$} & \multirow{4}{*}{$\begin{array}{l}77.8 \\
(75)\end{array}$} & \multirow[t]{4}{*}{-} & \multirow[t]{4}{*}{-} & & \\
\hline Velocity & 0.274 & 4.790 & 0.0017 & & & & & & & & \\
\hline Depth & 0.233 & 1.280 & 0.286 & & & & & & & & \\
\hline TOM & 0.232 & 1.267 & 0.291 & & & & & & & & \\
\hline Model III & 0.232 & 6.817 & $<0.000$ & \multicolumn{4}{|c|}{ Prediction dataset (validation dataset) } & \multirow{6}{*}{-} & \multirow{6}{*}{-} & \multirow{6}{*}{$\begin{array}{c}70.0 \\
(76.9)\end{array}$} & \multirow{6}{*}{$\begin{array}{c}60.2 \\
(63.9)\end{array}$} \\
\hline FF & 0.366 & 10.678 & 0.0000 & & & & & & & & \\
\hline Flow & 0.305 & 5.846 & 0.0004 & 66.7 & 54.5 & 30.8 & 77.8 & & & & \\
\hline Shear stress & 0.303 & 5.666 & 0.0005 & $(75.0)$ & (44.4) & (33.3) & (100.0) & & & & \\
\hline Velocity & 0.295 & 4.981 & 0.0013 & & & & & & & & \\
\hline Depth & 0.247 & 1.211 & 0.3131 & & & & & & & & \\
\hline
\end{tabular}

The Wilk's Lambda ( 0 perfect discrimination to 1 no discrimination), $F$ statistics and their $p$ values are given first for the overall model, then after elimination of the communities and/or sediment variable. The percentages of locations, which were correctly classified in the predictive and validation sub-sets, are also listed. FF - fine fraction; TOM - total organic matter. 
Table 4

Pearson correlations coefficients for the physical and chemical variables

\begin{tabular}{lcccccccc}
\hline & $\begin{array}{l}\text { Fine } \\
\text { fraction }\end{array}$ & Sand & Gravel & $\begin{array}{l}\text { Total } \\
\text { organic } \\
\text { matter }\end{array}$ & $\begin{array}{l}\text { Shear } \\
\text { stress }\end{array}$ & Flow & Velocity & Depth \\
\hline Fine fraction & 1.00 & $-0.98^{*}$ & $-0.32^{*}$ & 0.90 & $-0.50^{*}$ & $-0.41^{*}$ & $-0.44^{*}$ & $-0.32^{*}$ \\
Sand & $-0.98^{*}$ & 1.00 & 0.10 & -0.88 & $0.50^{*}$ & $0.38^{*}$ & $0.46^{*}$ & $0.23^{*}$ \\
Gravel & $-0.32^{*}$ & 0.10 & 1.00 & -0.31 & 0.11 & $0.25^{*}$ & 0.03 & $0.46^{*}$ \\
Total organic matter & $0.90^{*}$ & $-0.88^{*}$ & $-0.31^{*}$ & 1.00 & $-0.53^{*}$ & $-0.41^{*}$ & $-0.49^{*}$ & $-0.31^{*}$ \\
Shear stress & $-0.50^{*}$ & $0.50^{*}$ & 0.11 & -0.53 & 1.00 & $0.61^{*}$ & $0.94^{*}$ & 0.17 \\
Flow & $-0.41^{*}$ & $0.38^{*}$ & $0.25^{*}$ & -0.41 & $0.61^{*}$ & 1.00 & $0.69^{*}$ & $0.60^{*}$ \\
Velocity & $-0.44^{*}$ & $0.46^{*}$ & 0.03 & -0.49 & $0.94^{*}$ & $0.69^{*}$ & 1.00 & $0.22^{*}$ \\
Depth & $-0.32^{*}$ & $0.23^{*}$ & $0.46^{*}$ & -0.31 & 0.17 & $0.60^{*}$ & $0.22^{*}$ & 1.00 \\
\hline
\end{tabular}

Significant correlations $(p<0.05)$ marked with *.

When using prediction and validation sub-sets of equal size (50/50 proportion) the hit ratio of Model II is $64.5 \%$ for the prediction sub-set and $58 \%$ for the validation sub-set (compared to 58.8\% and 50.7\%, respectively, in Model I). Discarding sand, gravel and TOM (Model III) leads to a decrease in the hit ratio for both the prediction and the validation subsets $(56.5 \%$ and $61.4 \%)$.

Model II results are in agreement with natural conditions and other studies. Associations between organic matter and benthic communities are largely reported (e.g. Bakri \& Kittaneh, 1998; McRae et al., 1998). Snelgrove and Butman (1994) suggested that the amount of hydrodynamic energy and available organic material are more likely to be the primary driving forces, with depth and sediment grain size as secondary correlates. Rees, Pendle, Waldock, Limpenny, and Boyd (1999) also found that tidal current velocity, depth and sediment type help to explain the distribution of benthic assemblages. Although the hydrodynamic energy is difficult to measure in the field, the use of 3D hydrodynamic simulation models allows the prediction of these parameters at any instant or averaged over any period of time (Martins et al., 2001).

In summary, Model II provides the best predictions since fewer variables are discarded ( 2 instead of 3 for model III) and 2 groups with poor classification scores are removed. To test this model the samples belonging to groups $\mathrm{A}_{2}$ and $\mathrm{B}_{2 b}$ (which were eliminated from the validation dataset) were used as validation sets. The locations belonging to community $\mathrm{A}_{2}$ were classified into four different types of community $\left(\mathrm{A}_{1}-12.5 \% ; \mathrm{B}_{1}-25 \% ; \mathrm{B}_{2 a}-50 \%\right.$, II $\left.-12.5 \%\right)$. The high variance of the physical and chemical parameters measured at these stations explains the fuzziness of the classification. Half of the locations belonging to community $\mathbf{B}_{2 b}$, were allocated to community I while the other half was classified into community II. Those communities are the ones nearest to community $\mathrm{B}_{2 b}$.

\subsection{Prediction of benthic biotopes}

$B I_{\text {bio }}$ index was computed at the 77 sampling points using the classification functions (Eq. (2)) of Model II (Table 5). These new locations were allocated to the 
community with the highest posterior classification score probability $\left(\mathrm{prob}_{i}\right)$. Using Eq. (3) the benthic index was calculated and then the following classification was used: Marine $\left(B I_{\text {bio }}=1-1.4\right)$; Transition $\left(B I_{\text {bio }}=1.5-2.4\right)$; Estuarine $\left(B I_{\text {bio }}=2.5-\right.$ $3.4)$; Estuarine enriched $\left(B I_{\text {bio }}=3.5-4.4\right)$; Estuarine impoverished $\left(B I_{\text {bio }}=4.5-5\right)$. Results by station and by management unit are displayed in Fig. 2.

FF was the first variable selected in the model because of its significant correlation with the benthic index $\left(r^{2}=0.66\right)$. As stressed earlier, sediment grain size is an important factor determining benthic composition. Since a more densely sampled dataset is available for the same study area and period of time (153 sampling points Caeiro et al., 2003a), $B I_{\text {bio }}$ was interpolated using co-kriging, with FF as secondary variable. This interpolation method estimates the benthic index at an unmonitored location using a linear combination of neighboring index and FF values. The weights are such that the variance of the estimation error is minimum under the constraint of unbiasedness of the estimation (Goovaerts, 1997). Co-kriging usually improves the prediction when secondary and well correlated information is available, and it explicitly accounts for the spatial cross correlation between primary and secondary variables. For $B I_{\text {bio }}$ and $F F$ semivariogram models were fitted visually using a linear model of coregionalization (Goovaerts, 1997). A geometric anisotropy model allowed one to capture the longer range in the direction of azimuth $120^{\circ}$ that corresponds to the water flow (see Table 6 semivariogram model parameters).

The spatial pattern of the $B I_{\text {bio }}$ is similar to the spatial distribution of benthic communities found by Rodrigues and Quintino (1993) (Figs. 1 and 3) although some differences are expected due to changes in the sediment characteristics (see FF spatial distribution in Fig. 4). The marine community characterized by clean sand sediments is found at the entrance of the estuary, but in comparison to the 1986 campaign, this community moved to the entrance of the North Channel replacing former transition communities. These changes were already noticed in a 1997 study conducted along the Entrance Channel and the Northern Channel (Rodrigues \& Quintino, 2002). These authors stress that these changes are related to dredging and the resulting decrease in organic load. According to them this induces biodiversity loss, associated with inward spread of the open sea marine assemblage, which is less rich and abun-

Table 5

Classification functions $\left(W_{j}\right)$ for each community $z$ of Model II for $B I_{\text {bio }}$ calculation

\begin{tabular}{llcrrr}
\hline Variable $(j)$ & $\begin{array}{l}\text { Marine type } \\
\left(\mathrm{A}_{1}\right)\end{array}$ & $\begin{array}{l}\text { Transition } \\
\text { region }\left(\mathrm{B}_{1}\right)\end{array}$ & $\begin{array}{l}\text { Estuarine } \\
\text { type }\left(\mathrm{B}_{2 a}\right)\end{array}$ & $\begin{array}{l}\text { Estuarine } \\
\text { impoverished }(\mathrm{I})\end{array}$ & $\begin{array}{l}\text { Estuarine } \\
\text { enriched (II) }\end{array}$ \\
\hline FF & -1.68786 & -1.62273 & 0.74695 & -0.32941 & 3.22446 \\
Flow & 3.42315 & -0.15635 & -0.55361 & -0.28041 & -0.34494 \\
Shear stress & 6.52528 & -0.54224 & -0.19505 & -1.56882 & -1.21969 \\
Velocity & -6.15078 & 0.60679 & 0.63274 & 0.97355 & 0.38343 \\
Depth & -0.58882 & 0.56611 & -0.09986 & -0.09487 & -0.02608 \\
TOM & -0.13869 & 0.46169 & -1.08579 & 0.94509 & 0.26584 \\
Constant $\left(C_{z}\right)$ & -6.87994 & -1.81065 & -1.20610 & -2.24548 & -5.26877 \\
\hline
\end{tabular}

$\mathrm{FF}$ - fine fraction; TOM - total organic matter. 


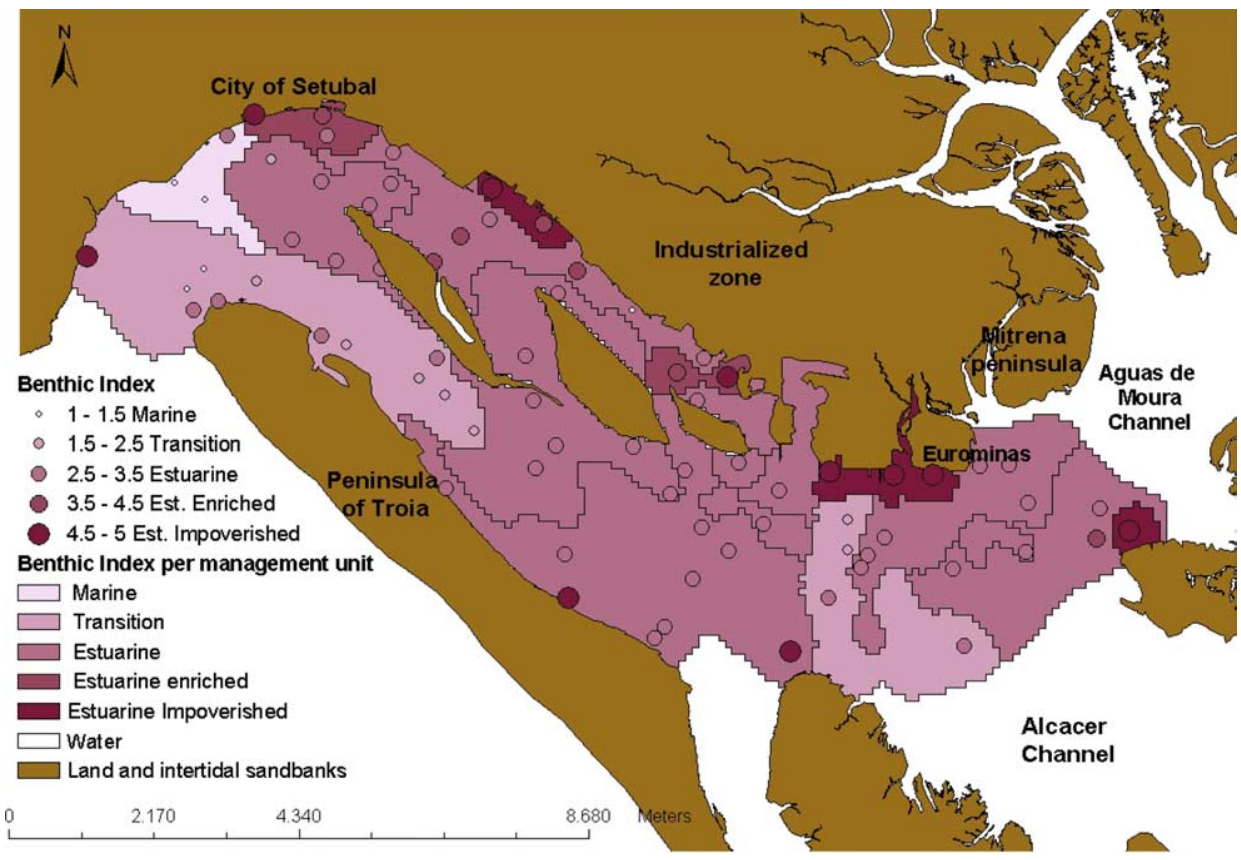

Fig. 2. Maps of the index $B I_{\text {bio }}$ computed at sampled locations and averaged within management units in the Sado Estuary.

dant, and typical of coarser clean sands. The lower river flux entering into the estuary during the last decades can also explain these benthic changes.

The transition region follows the marine type community, spreading over a large area more through the Southern Channel (Fig. 3). In comparison with the earlier spatial distribution of benthic assemblages (Rodrigues \& Quintino, 1993) the transition regions seem to have spread to inner parts of the estuary, replacing a former small area of marine community existent near the sandbank (Fig. 1). In agreement with benthic sampling studies undertaken in the Southern Channel in 1999 (Carvalho et al., 2001), changes involve an increase in abundance and species richness, associated to organically enriched areas. This enrichment is also illustrated by the presence of larger areas of estuarine enriched and impoverished communities near Eurominas industry, replacing the estuarine type community (Figs. 1 and 3).

The estuarine enriched and impoverished communities associated with higher organic load are located near the urban area of the city of Setúbal, and in small areas along the north margin, near industrial wastewater discharges. At the entrances of Águas de Moura and Alcácer Channels two sampling points have high values of the Benthic Index (Fig. 2). These locations have low hydrodynamics and low depths, which yield high organic loads (Fig. 4), but may also be subjected to non-point pollution runoff and deposition. These non-point sources could be due to aquaculture and rice field activities upstream of those channels. Most contaminants entering 
estuarine bodies of water become particle-bound (Alden, Weisberg, Ranasinghe, \& Dauer, 1997) and are eventually concentrated in fine-grained sediments where most low-dissolved oxygen events occur (Diaz \& Rosenberg, 1995).

The distribution of communities predicted in 2000 and 2001 is similar to the ones found in 1986 (Fig. 5). There was however a decrease in the proportion of communities belonging to the transition region (species richness peak) balanced by a gain in the estuarine communities, resulting in a loss of biodiversity, as already stressed by Rodrigues and Quintino (2002).

The benthic biotopes gradient used in the $B I_{\text {bio }}$ index has been delineated for the Sado Estuary by other authors, based on multivariate ordination analyses and relationships with physical and chemical data (Rodrigues \& Quintino, 2002). These multivariate methods were found to be powerful tools for assessing perturbations to benthic infauna assemblages (Smith et al., 2001). Those gradients corroborate Pearson and Rosenberg's (1978) results; they suggested that benthic respond sequentially to different levels of stress with species replacement occurring at the lowest level, while loss in diversity, abundance, and biomass occurs at increasingly higher levels of stress. These gradients were also successfully incorporated in other benthic indices to allow the evaluation of their sensitivity to an increasing stress gradient (e.g. Majeed, 1987; Grall \& Glémarec, 1997; Weisberg et al., 1997; Borja et al., 2000). Other studies developed a model that predicts solids accumulation on the seabed and associated changes in the benthic faunal community, using the infauna trophic index. From quantitative relationships between benthic community descriptors and solids accumulation (including hydrodynamics and depth), the level of benthic community impact in marine cage farms was predicted (Cromey, Nickell, \& Black, 2002). Degraer et al. (2002) demonstrated that knowledge of the physical and chemical environments help predicting the occurrence of the macrobenthos.

Nevertheless, further testing and refinement of this Index should be conducted to allow a correct prediction of all type of communities found in the studied estuary and new data should be collected to validate this model. This index should also be tested in other estuarine ecosystems.

No single method is likely to produce stress classification with an acceptable rate of errors. Ecological stress, from any source, is best measured by multiple methods or analysis under different assumptions. The consistency of classification obtained using different approaches would provide the robustness necessary to judge the reliability of a stress classification (Dauer, 1993). Combining the index with other

Table 6

Semivariogram models for the co-kriging calculation, according to method properties in Geostatistical Analyst $^{\circledR}$

\begin{tabular}{llllll}
\hline Variable & Nugget & Model & Partial sill & Major range & Minor range \\
\hline Fine fraction & 0.2 & Spherical & 0.7 & 1850 & 1334 \\
Benthic index & 0.4 & Spherical & 1.45 & 1850 & 1334 \\
\hline
\end{tabular}

Angular tolerance of $23^{\circ}$ and lag distance of $450 \mathrm{~m}$ were used for the computation of experimental semivariograms. 


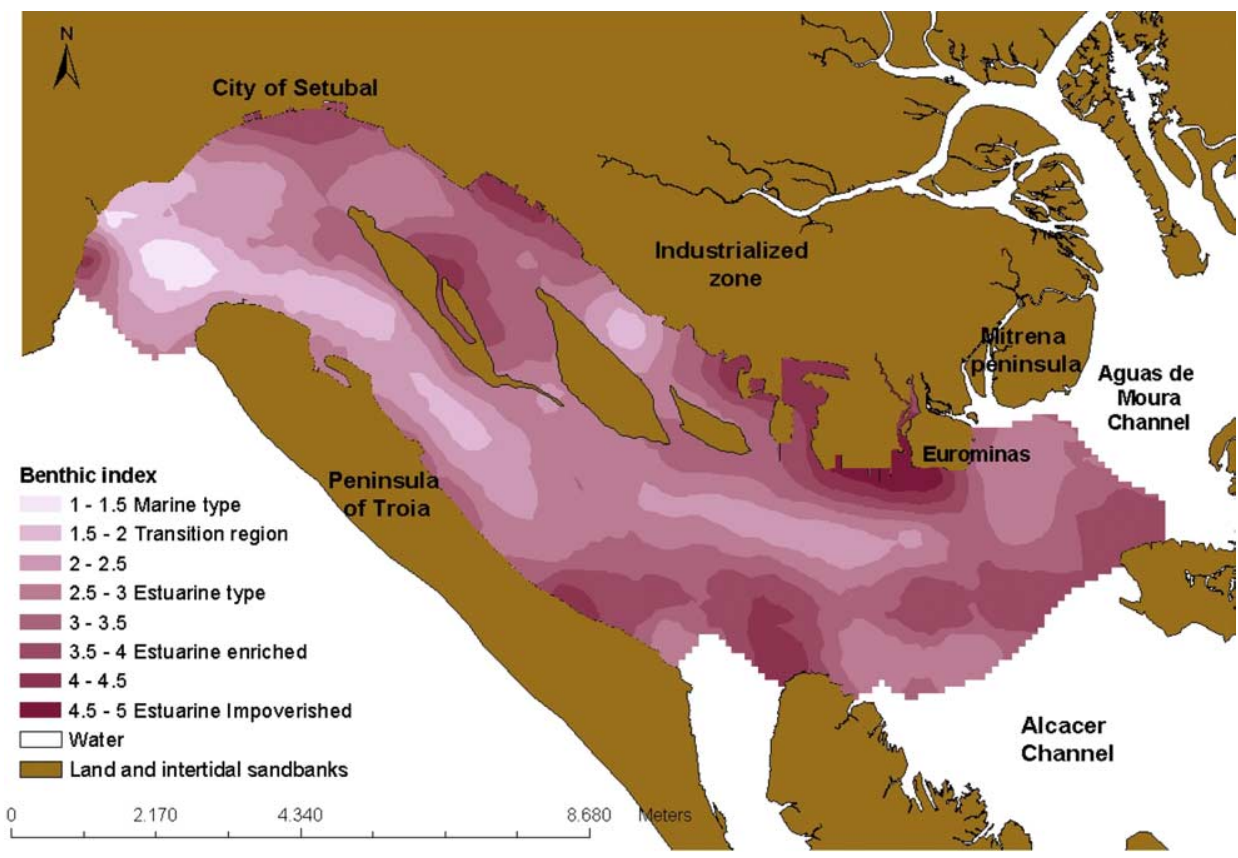

Fig. 3. Spatial distribution of the $B I_{\text {bio }}$ in Sado Estuary.

measures of habitat quality, such as direct measures of sediment contamination and toxicity, can reduce misinterpretation of the data and provide a powerful weightof-evidence approach to assessing the overall condition of a site, estuary or region (Van Dolah, Hyland, Holland, Rosen, \& Snoots, 1999).

The results of the index will be combined with contaminant and toxicity data representative of each management unit according to a Triad approach (Chapman, 1996). The sediment quality assessment of the management units will evaluate the State and Impact of the estuary according to the Driving Forces-Pressures-StateImpact-Responses (DPSIR) indicators framework for data syntheses and management (Caeiro et al., 2002). This framework is used to link social and economic pressures with environmental quality, making it possible to formulate societal Responses that result in the formulation of an environmental policy.

\section{Conclusions}

Over the past two decades, indices of biological conditions have been adopted as tools for comprehensive monitoring of ambient water quality, and increasingly they are being incorporated into regulations in the form of numerical, biological criteria (Jacobson, 2000). The emphasis on benthic indices is appropriate because central to the assessment of a system's viability or health is the quality of its benthic habitats 


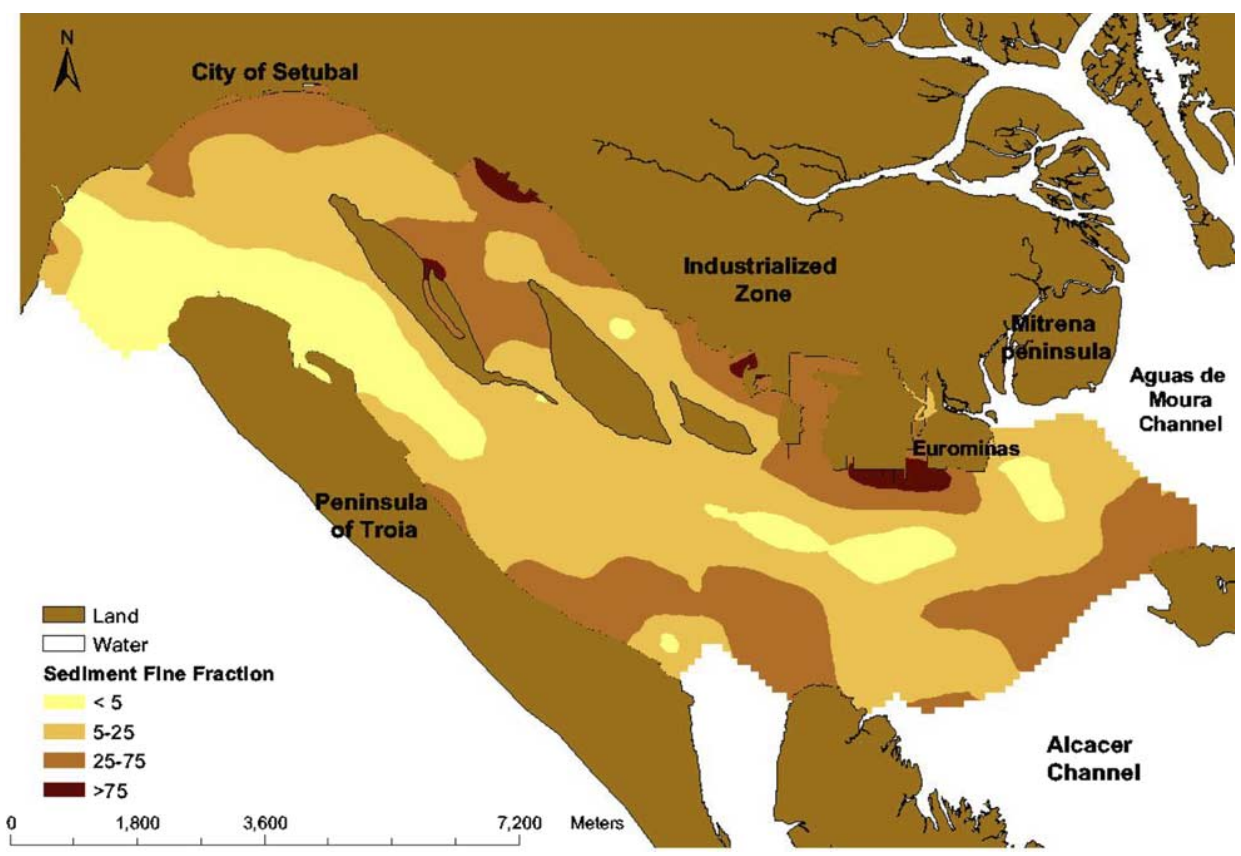

Fig. 4. Spatial distribution of sediment fine fraction $(<63 \mu \mathrm{m})$ in Sado Estuary.

and the communities they support (Diaz et al., 2003). Also they could be very helpful for estuarine quality compliance, namely according to European Water Framework Directive (2000/60/EC). Benthic indices are usually statistically robust, biologically meaningful and very cost effective (Roberts, Gregory, \& Foster, 1998). Despite their limitations, they have been proven to be valuable tools for assessing sediment quality in a variety of estuarine habitats (Engle \& Summers, 1999).

Researchers are working towards a better understanding and management of environmental quality in estuaries using benthic community and biological indicators for estimation of the sediment condition, thus moving away from the use of traditional physical/chemical indicators. But the weakness of most of the benthic studies is the need for large databases and benthic community data that are very time consuming to develop and have often been criticized (Olsgard, Somerfield, \& Carr, 1997). Several studies are exploring easier and less time consuming ways to analyze the benthic community structure for pollution assessment, such as the use of: (i) acoustic and optical imaging, like side scan sonar images, multibeam echosounders or sediment profile images (e.g. Nilsson \& Rosenberg, 1997; Degraer et al., 2002; Santoro, Tonielli, \& Simioli, 2002); (ii) lower levels of taxonomic discrimination required to detect pollution: (e.g. Warwick, 1988; Olsgard et al., 1997; Drake, Baldó, Sáenz, \& Arias, 1999), and (iii) trophodynamic groups classification (e.g. Mucha \& Costa, 1999). 
In this paper, we presented an index methodology to predict the occurrence of macrobenthic communities, using physical and chemical variables such as sediment type, organic matter, depth and hydrodynamic parameters. This permits one to predict the occurrence of benthic biotopes at unsampled locations in a cost-effective way. The index shows that the distribution of benthos in the Sado Estuary is characterized at the entrance of the estuary by marine and transition communities, undisturbed and with high species richness. The transition region spreads over a large area through the Southern Channel. The more disturbed and organic enriched communities are found in the North Channel, near industrialized areas, and in a small area at the entrance of Águas de Moura Channel. Comparison with the benthic communities identified 20 years ago shows a decrease in communities belonging to the transition region while the estuarine and more disturbed communities have gained.

We want to emphasize that it would be inappropriate to apply this index to a set of conditions that are not similar to the original data used for its development, and no extrapolation should be conducted beyond the limits of the datasets used. Nevertheless further testing is needed, and the use of $B I_{\text {bio }}$ allowed an easy synthesis of the ecological information required to visualize biotope gradients. Although this index may not be directly applicable in other estuarine systems, the methodology can be applied elsewhere.

The benthic index methodology for classifying habitats could be combined with imaging techniques for bathymetric-sedimentological mapping. Remote-sensing allows mapping the sediment substrate and calculate the physical and chemical sediment parameters strongly correlated with benthic habitat, such as depth, texture, presence of dissolve oxygen, presence of gas voids or redox potential discontinuity. Once the most appropriate imaging technique for estuaries have been selected these data can be used in a discriminant model, instead or in addition to time consuming field sampling. Those techniques statistically assess differences in benthic habitat and have already been used in estuarine benthic studies (e.g. Diaz et al., 2003).

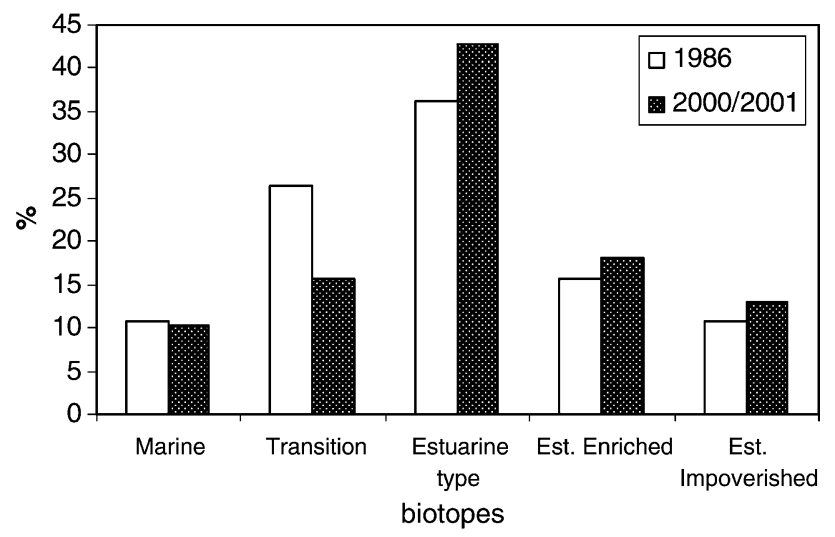

Fig. 5. Frequency distributions of the biotope types found in 1986 and the ones predicted in 2000/2001. 


\section{Acknowledgments}

Sandra Caeiro's work was supported by a PRODEP Program grant. The research was approved by the Portuguese Science and Technology Foundation and POCTI (Research Project POCTI/BSE 35137/99) and financed by FEDER. The authors would like to express their gratitude to Prof. Ana Rodrigues for making the data available and personal communications. Comments by two anonymous reviewers improved the presentation of this paper.

\section{References}

Alden, R. W., Dauer, D. M., Ranasinghe, J. A., Scott, L. C., \& Llansó, R. J. (2002). Statistical verification of the chesapeake bay benthic index of biotic integrity. Environmetrics, 13, 473-498.

Alden, R. W., Weisberg, S. B., Ranasinghe, J. A., \& Dauer, D. M. (1997). Optimizing temporal sampling strategies for benthic environmental monitoring programs. Marine Pollution Bulletin, 34, 913-922.

Anderson, B., Hunt, J., Phillips, B., Newman, J., Tjeerdema, R., Wilson, C. J., Kapahi, G., Sapudar, R. A., Stephenson, M., Puckett, H. M., Fairey, R., Oakden, J. M., Lyons, M., \& Birosik, S. (1998). Sediment chemistry, toxicity and benthic coomunity conditions in selected water bodies of the Los Angeles Region. Final Report, California State Water Resources Control Board, Sacramento, CA, USA, $232 \mathrm{pp}$.

Bakri, D., \& Kittaneh, W. (1998). Physicochemical characteristics and pollution indicators in the intertidal zone of Kuwait: implications for benthic ecology. Environmental Management, 22, 415-424.

Bascom, W. (1982). The effects of waste disposal on the coastal waters of sourthern California. Environmental Science and Technology, 16, 226A-236A.

Bellan, G. (1980). Relationships of pollution to rocky substratum polychaetes on the french mediterranean coast. Marine Pollution Bulletin, 11, 318-321.

Bellan, G., Desrosiers, G., \& Willsie, A. (1988). Use of an annelid pollution index for monitoring a moderately polluted littoral zone. Marine Pollution Bulletin, 19, 662-665.

Bergen, M., Weisberg, S. B., Smith, R. W., Cadien, D., Dalkey, A., Montagne, D., et al. (2001). Relationship between depth, sediment, latitude, and the structure of benthic infaunal assemblages on the mainland shelf of southern California. Marine Biology, 138, 637-647.

Borja, A., Franco, J., \& Pérez, V. (2000). A marine biotic index to establish the ecological quality of softbottom benthos within european estuaries and coastal environments. Marine Pollution Bulletin, 40, $1100-1114$.

Borja, A., Muxika, I., \& Franco, J. (2003). The application of a marine biotic Index to different impact sources affecting soft-bottom benthic communities along European coasts. Marine Pollution Bulletin, 46, 835-845.

Caeiro, S., Costa, M. H., Paínho, M., Ramos, T. B. (2002). Sado Estuary Environmental Management: A GIS Approach. In Proceedings of Euroworkshop ECO-GEOWATER GI and Water Resources Assessment, Geographical Information Systems International Group GISIG (pp. 1-13). Oxford, England.

Caeiro, S., Goovaerts, P., Painho, M., \& Costa, M. H. (2003a). Delineation of estuarine management areas using multivariate geostatistics: the case of sado estuary. Environmental Science and Technology, 37, 4052-4059.

Caeiro, S., Goovaerts, P., Painho, M., Costa, M. H., \& Sousa, S. (2003b). Spatial sampling design for sediment quality assessment in estuaries. Environmental Modeling and Software, 18, 853859.

Caeiro, S., Nunes, L., Goovaerts, P., Costa, M. H., Cunha, M. C., Painho, M., \& Ribeiro, L. (2004). Optimisation of an estuarine monitoring program: selecting the best spatial distribution. In A. Soares, J. Gomez-Hernandez, \& R. Froidevaux (Eds.), GeoENV IV Geostatistical for Environmental Applications (pp. 355-366). Dordrecht: Kluwer Academic Press. 
Carvalho, S., Ravara, A., Quintino, V., \& Rodrigues, A. M. (2001). Macrobenthic community characterization of an estuary from the western coast of Portugal (Sado estuary) prior to dredging operations. Boletín Instituto Español de Oceanografia, 17, 179-190.

Chapman, P. M. (1996). Presentation and interpretation of sediment Quality Triad data. Ecotoxicology, 5, 327-339.

Chapman, P. M., Dexter, R. N., \& Long, E. R. (1987). Synoptic measures of sediment contamination, toxicity and infauna community composition (the Sediment Quality Triad) in San Francisco Bay. Marine Ecology Progress Series, 37, 75-96.

Clarke, K. R. (1993). Non-parametric multivariate analyses of changes in communty structure. Australian Journal of Ecology, 18, 117-143.

Cromey, C. J., Nickell, T. D., \& Black, K. D. (2002). DEPOMOD - modelling the deposition and biological effects of waste solids from marine cage farms. Aquaculture, 214, 211-239.

Dauer, D. M. (1993). Biological criteria, environmental health and estuarine macrobenthic community structure. Marine Pollution Bulletin, 26, 249-257.

Degraer, S., Van Lanker, V., Moerkerke, G., Van Hoey, G., Vincx, M., Jacobs, P., \& Henriet, J. (2002). Intensive evaluation of the evolution of a protected benthic habitat: HABITA T. Final report. Federal Office for Scientific, Technical and Cultural Affairs (OSTC) - Ministry of the Flemish Community, Environmental and Infrastructure Department. Waterways and Marine Affairs Administration, Coastal Waterways. Brussels, Belgium.

DelValls, T. A., Forja, J. M., \& Gómez-Parra, A. (1998). Integrated assessment of sediment quality in two littoral ecosystems from the gulf of cádiz, Spain. Environmental Toxicology and Chemistry, 17, 1073-1084.

Diaz, R. J., Cutter, G. R., \& Dauer, D. M. (2003). A comparison of two methods for estimating the status of benthic habitat quality in the Virginia Chesapeake Bay. Journal of Experimental Marine Biology and Ecology, 285-286, 371-381.

Diaz, R. J., \& Rosenberg, R. (1995). Marine benthic hypoxia: a review of its ecological effects and the behaviour responses of benthic macrofauna. Oceanography and Marine Pollution Annual Review, 33, 245-303.

Drake, P., Baldó, F., Sáenz, V., \& Arias, A. M. (1999). Macrobenthic community structure in estuarine pollution assessment on the gulf of cádiz (SW Spain): is the phylum-level meta-analysis approach applicable? Marine Pollution Bulletin, 38, 1038-1047.

Eaton, L. (2001). Development and validation for biocriteria using benthic macroinvertebrates for North Carolina Estuarine Waters. Marine Pollution Bulletin, 42(1), 23-30.

Engle, V., \& Summers, J. K. (1998). Determining the causes of benthic condition. Environmental monitoring and assessment, 51, 381-397.

Engle, V., \& Summers, J. K. (1999). Refinement, validation and application of a benthic condition index for northern gulf of mexico estuaries. Estuaries, 22, 624-635.

Engle, V., Summers, J. K., \& Gaston, G. (1994). A benthic index of environmental condition of Gulf of Mexico Estuaries. Estuaries, 17, 372-384.

Ferreira, J. G. (2000). Development of an estuarine quality index based on key physical and biogeochemical features. Ocean \& Coastal Management, 43, 99-122.

Gibson, G. R., Bowman, M. L., Gerritsen, J., \& Snyder, B. D. (2000). Estuarine and Coastal Marine Waters: Bioassessment and Biocriteria Technical Guidance. EPA 822-B-00-024. Environmental Protection Agency, Office of Water, Washington, DC, USA.

Gleason, H. A. (1922). On the relation between species and area. Ecology, 3, 158.

Goovaerts, P. (1997). Geostatistics for natural resources evaluation. New York, USA: Oxford University Press.

Grall, J., \& Glémarec, M. (1997). Using biotic indices to estimate macrobenthic community perturbations in the bay of brest. Estuarine, Coastal and Shelf Science, 44, 43-53.

Hair Jr., Anderson, R. E., \& Tatham, R. L. (1992). Multivariate data analysis with readings. New York: Macmillan Publishing Company, 449 pp.

Jacobson, P. T. (2000). Evaluation of multi-metric bioassessment as an approach for assessing impacts of entrainment and impingement under Section 316(b) of the Clean Water Act. Environmental Science \& Policy, 3, S107-S115. 
Jeffrey, D. W., Wilson, J. G., Harris, C. R., \& Tomlinson, D. L. (1985). The application of two simple indices to Irish estuary pollution status. In J. G. Wilson \& Halcrow (Eds.), Estuarine management and quality assessment (pp. 147-165). London, Englad: Plenum Press.

Leppakowski, E. (1975). Assessment of degree of pollution on the basis of macrozoobenthos in marine and brackish-water environments. Acta Academiae Aboensis Ser B, 35, 1-89.

Majeed, S. A. (1987). Organic matter and biotic indices on the beaches of north brittany. Marine Pollution Bulletin, 18, 490-495.

Martins, F., Leitão, P., Silva, A., \& Neves, R. (2001). 3D modeling in the Sado estuary using a new generic vertical discretization approach. Oceanologica Acta, 24, S51-S62.

McLusky, D. S., \& Elliott, M. (2004). The estuarine ecosystem. Ecology, threats and management (third ed.). New York USA: Oxford University Press.

McManus, J. W., \& Pauly, D. (1990). Measuring ecological stress: variations on a theme by R.M. Warwick. Marine Biology, 106, 305-308.

McRae, G., Camp, D. K., Lyons, W. G., \& Dix, T. L. (1998). Relating benthic infaunal community structure to environmental variables in estuaries using nonmetric multidimensional scaling and similarity analysis. Environmental monitoring and assessment, 51, 233-246.

Mucha, A. P., \& Costa, M. H. (1999). Macrozoobenthic community structure in two Portuguese estuaries: relationship with organic enrichment and nutrient gradients. Acta Oecologica, 20, 363-376.

Nilsson, H. C., \& Rosenberg, R. (1997). Benthic habitat quality assessment of an oxygen stressed fjord by surface and sediment profile images. Journal of Marine Research, 11, 249-264.

Olsgard, F., Somerfield, P. J., \& Carr, M. R. (1997). Relationships between taxonomic resolution and data transformation in analyses of a macrobenthic community along an established pollution gradient. Marine Ecology Progress Series, 149, 173-181.

Paul, J. F., Gentile, J. H., Scott, K. J., Schimmel, S. C., \& Campbell, D. E. (1999). EMAP - Virginian Province Four-Year Assessment (1990-93). National Health Environmental Effects Research Laboratory, Atlantic Ecology Division, EPA, Narragansett, RI, USA.

Paul, J. F., Scott, K. J., Campbell, D. E., Gentile, J. H., Strobel, C. J., Valente, R. M., et al. (2001). Developing and applying a benthic index of estuarine condition for the virginian biogeographic province. Ecological Indicators, 1, 83-99.

Pearson, T. H., \& Rosenberg, R. (1978). Macrobenthic succession in relation to organic enrichment and pollution of the marine environment. Oceanography and Marine Pollution Annual Review, 16, 229-311.

Ranasinghe, J. A., Frithsen, J. B., Kutz, F. W., Paul, J. F., Russell, D. E., Batiuk, A. R., et al. (2002). Application of two indices of benthic community condition in chesapeake bay. Environmetrics, 13, 499-511.

Ranasinghe, J. A., Weisberg, S. B., Dauer, D. M., Schaffner, L. C., Diaz, R. J., \& Frithsen, J. B. (1994). Chesapeake Bay Benthic Community Restoration Goals. CBP/TRS 107/94, Chesapeake Bay program Office, USEPA, Annapolis, Maryland, USA, 49 pp.

Rees, H. L., Pendle, M. A., Waldock, D. S., Limpenny, D. S., \& Boyd, S. E. (1999). A comparison of benthic biodiversity in the North Sea, english channel, and celtic seas. ICES Journal of Marine Science, $56,228-246$.

Rhoads, D. C., \& Germano, J. D. (1986). Interpreting long-term changes in benthic community structure: a new protocol. Hydrobiologia, 142, 291-308.

Roberts, R. D., Gregory, M. R., \& Foster, B. A. (1998). Developing and Efficient Macrofauna Monitoring Index from an Impact Study - A Dredge Spoil Example. Marine Pollution Bulletin, 36, 231-235.

Rodrigues, A. M. (1992). Environmental Status of a Multiple Use Estuary, through the Analysis of Benthic Communities: The Sado Estuary, Portugal. Doctoral Thesis, Univ. Sterling. England.

Rodrigues, A. M., \& Quintino, V. M. S. (1993). Horizontal biosedimentary gradients across the sado estuary, W. Portugal. Netherlands Journal of Aquatic Ecology, 27, 449-464.

Rodrigues, A. M., \& Quintino, V. (2002). Estuarine sediment assessment prior to dredging: integration of benthic ecotoxicology studies. Journal of Coastal Research, 34, 306-317.

Santoro, F., Tonielli, R. Lauro, M., \& Simioli, A. (2002). A GIS Application to Study the Influence of Submarine Topography and Morphology on the Development of Nearshore Benthic Fauna of the Soorrento Peninsula (Sourthern Italy). In F. Veloso-Gomes, F. Taveira-Pinto, L. Neves (Eds.), Proceedings of Littoral 2002, The Changing Coast. European Coastal Zone Association for Science 
and Technology (EUROCOAST) - Portugal Association /EUCC - The Coastal Union, (pp. 195-200). Porto, Portugal.

Satsmadjis, J. (1985). Comparison of indicators of pollution in the mediterranean. Marine Pollution Bulletin, 16, 395-400.

Schimmel, S. C., Melzian, B. D., Campbell, D. E., Benyi, S. J., Rosen, J. S., \& Buffum, H. W. (1994). Statistical Summary: EMAP - Estuaries Virginian Province, 1991. Office of Research and Development, Environmental Research Laboratory, USEPA, Narragansett, RI, USA.

Schmidt, T. S., Soucek, D. J., \& Cherry, D. S. (2002). Modification of an ecotoxicological rating to bioassess small acid mine drainage-impacted watersheds exclusive of benthic macroinvertebrate analysis. Environmental Toxicology and Chemistry, 21, 1091-1097.

Shannon, C. E., \& Weaver, W. (1949). The mathematical theory of communication. Urbana, Illinois, USA: The University of Illinois Press, 115 pp.

Smith, R. W., Bergen, M., Weisberg, S. B., Cadien, D., Dalkey, A., Montagne, D., et al. (2001). Benthic responses index for assessing infaunal communities on the southern California mainland shelf. Ecological Applications, 11, 1073-1087.

Snelgrove, P. V. R., \& Butman, C. A. (1994). Animal-sediment relationships revisited: cause versus effect. Oceanography and Marine Pollution Annual Review, 32, 111-177.

Strobel, C. J., Buffum, H. W., Benyi, S. J., Petrocelli, E. A., Reifsteck, D. R., \& Keith, D. J. (1995). Statistical Summary. EMAP - Estuaries Virginian Province - 1990 to 1993. National Health Environmental Effects Research Laboratory, Atlantic Ecology Division, USEPA, Narragansett, RI, USA.

Van Dolah, R. F., Hyland, J. L., Holland, A. F., Rosen, J. S., \& Snoots, T. R. (1999). A benthic index of biological integrity for assessing habitat quality in estuaries of the southeastern USA. Marine Environmental Research, 48, 269-283.

Warwick, R. M. (1988). The level of taxonomic discrimination required to detect pollution effects on marine benthic communities. Marine Pollution Bulletin, 19(6), 259-268.

Warwick, R. M., \& Clarke, K. R. (1991). A comparison of some methods for analyzing changes in benthic community structure. Journal of Marine Biology Assessment UK, 71, 225-244.

Warwick, R. M., \& Clarke, K. R. (1995). New biodiversity measures reveal a decrease in taxonomic distinctness with increasing stress. Marine Ecology Progress Series, 129, 301-305.

Weisberg, S. B., Frithsen, J. B., Holland, A. F., Paul, J. F., Scott, K. J., Summers, J. K., Wilson, H. T., Heimbuch, D. G., Gerritsen, J., Schimmel, S. C., \& Latimer, R. W. (1993). Virginian Province Demonstration Project Report, EMAP-Estuaries, 1990. EPA/620/R-93/006, Office of Research and Development, USEPA, Washington, DC, USA.

Weisberg, S. B., Ranasinghe, J. A., Dauer, D. M., Schaffner, L. C., Diaz, R. J., \& Frithsen, J. B. (1997). An estuarine benthic index of biotic integrity (B-IBI) for Chesapeake Bay. Estuaries, 20, 149-158.

Wilson, J. G., \& Jeffrey, D. W. (1994). Benthic biological pollution indices in estuaries. In K. J. M. Kramer (Ed.), Biomonitoring of coastal waters and estuaries (pp. 311-327). Boca Raton, USA: CRC Press. 